Meta

Journal des tradlucteurs

Translators' Journal

\title{
The Semantic and the Cognitive in the Text: A Problem in Equivalence
}

\section{Vilen Komissarov}

Volume 32, numéro 4, décembre 1987

URI : https://id.erudit.org/iderudit/003335ar

DOI : https://doi.org/10.7202/003335ar

Aller au sommaire du numéro

Éditeur(s)

Les Presses de l'Université de Montréal

ISSN

0026-0452 (imprimé)

1492-1421 (numérique)

Découvrir la revue

Citer cet article

Komissarov, V. (1987). The Semantic and the Cognitive in the Text: A Problem

in Equivalence. Meta, 32(4), 416-419. https://doi.org/10.7202/003335ar d'utilisation que vous pouvez consulter en ligne.

https://apropos.erudit.org/fr/usagers/politique-dutilisation/ 


\section{THE SEMANTIC AND THE COGNITIVE IN THE TEXT : A PROBLEM IN EQUIVALENCE}

VILEN KOMISSAROV

Moscow State Institute of Foreign Languages, Moscow, USSR

The problem of equivalence has been traditionally regarded as pivotal in the theory and practice of translation. As a rule, the translator's aim is to produce the closest possible equivalent of the source text message in the target language. The trouble begins when one tries to define what that message is and gets bogged down in the complexities of text semantics.

It is obvious that the problem of translation equivalence cannot be tackled without first identifying the meaningful components that make up the global contents of the text. And among other things, it seems essential to define the relative importance of the cognitive information conveyed in the text and its semantic structure which is the result of the interworking of the meaningful language units.

At the beginning of a speech act is the speaker's intention of communicating part of his cognitive knowledge to one or more receptors of that information. To this end he selects the appropriate language units and arranges them in speech sequences (texts) whose semantics must inform the receptor what cognitive content is being transmitted. Thus the semantic serves as the vehicle for the cognitive end it is the transfer of the latter that is the purpose of speech communication. It follows that the cognitive is the message that should be reproduced in the target text.

All this, however, is only part of the true picture. For the transfer of the cognitive is achieved in a fairly complicated manner. First, the speaker may fail, partially or completely, to select the language units adequately conveying the intended cognitive entity. Second, the text actualizes only a part of the language units' meanings, which has to be deduced by the receptor. Third, text semantics conveys only part of the message, which is supplemented by the additional information deduced by the communicants from their background knowledge, interpersonal relations and the circumstances of the intercourse. Fourth, the contents of the text are not equally accessible to different receptors due to the dissimilarity of the background and linguistic knowledge that each of them possesses. Some parts of the contents - its illocutionary function in the first place are grasped by all receptors, while some bits of the information transmitted in the text are accessible to just a few of them. As a rule, partial understanding is sufficient for the desired communicative effect. And fifth, each receptor evaluates and modifies the information he has gleaned from the text contents within the framework of his own personality and cognitive knowledge. His reaction to the message is, therefore, subjective and may differ both from the speaker's intention and the potential communicative effect of the text.

To sum up, the message conveyed by the text includes a number of meaningful components which interwork with the cognitive worlds of the communicants. At least four contensive levels can be distinguished :

1. The speaker's cognitive knowledge which he intended to communicate. 
2. The semantic content produced by the combination of the meaningful language units which make up the text, and, more or less correlated, if not identical, to the speaker's communicative intention.

3. The specific contextual content resulting from the projection of the semantic content against the background information and the specific features of the particular speech act.

4. The received content which is the part of the contextual content accessible to the particular receptor under the specific circumstances of information retrieval and which becomes part of the receptor's cognitive knowledge.

If each level is assessed in terms of its relative communicative value, it is the first and the fourth that easily get the top marks, with the third following closely behind and the second relegated to the lowest position. The aim of the communication is apparently best achieved if the cognitive knowledge extracted by the receptor from the text coincides with the speaker's intention. The major importance of the two cognitive elements seems indisputable, though they are both subjective since they are dependant on the báckground knowledge of the communicants. Of obvious significance is also the specific contextual content of the text as it is there that the receptor is to look for the information addressed to him. And it is through the analysis of this part of the message that the receptor gets his subjective version of what the speaker meant to communicate.

It follows that the semantic in the text should be assigned the role of an auxiliary in the service of the cognitive. The communicants' main concern is that part of the cognitive which is relevant to the particular communicative situation. In most cases the relevant information can be expressed with different linguistic patterns, which gives the impression that the cognitive exists apart from, and independent of, the semantic. Indeed, the semantic is often regarded as the surface form hiding the true content, as a barrier that has to be cleared to get to the cognitive.

This understanding of the communicative process exercices a great influence upon the modern concepts of translation equivalence. The theory of translation has always emphasized the communicative aspects of the object of its investigation. Obviously, interlingual communication is also aimed at transmitting some cognitive knowledge from the author of the source text to the receptor of the target text. And an equivalent translation should make this transmission possible. This puts emphasis on the role of the specific contextual content of the source text and of the cognitive knowledge of the translation receptor. The former is the translator's source of information about the author's intention which should be reproduced in the target text, while the latter gives the translator an idea to what extent the receptor is capable of appropriating the cognitive knowledge to be transmitted to him.

Hence, most of the present-day speculations about the nature of translation equivalence are centered on two determinants. First, the role of the individual features of the speech act is considered to be decisive. It is suggested that since the contextual content of the text wholly depends on the who, when, where and why of the particular speech act, a change in any of these factors will produce a different text, which will call for a different translation. Second, great emphasis is laid on orienting the translating process towards the receptor. The concept of equivalence in receptor-oriented translation must needs be relative. The question "Is this translation equivalent ?" is answered with another question "Equivalent for whom ?", the assumption being that the translator's main duty is to ensure mutual understanding between the given participants in interlingual communication in each particular translation event.

This attitude inevitably results in downgrading the role of the semantic and, hence, of the linguistic, in the translating process. In fact, it postulates the negative role 
of the semantic which is presumed to be the cause of undue literalism and interlanguage interference barring access to the cognitive. If communication through translation passes from the cognitive to the cognitive with the semantic an undesirable, if unavoidable obstacle, the obvious conclusion is that the theory of translation should not be concerned with text semantics, that is, with meaningful language units. Consequently, the theory of translation can be communicative, interpretative or psychological, but never linguistic. This conclusion seems to be well in line with our understanding of the phenomenon of human communication.

It is not my intention to question the validity of this line of argumentation. I would like to suggest, however, that its relevance to the process of translation has been exaggerated. True, any text, any utterance, even a simple sentence such as, for instance, "I like apples", may, in each particular act of human intercourse, convey different communicative intentions. It may perform different illocutionary functions and therefore it may have more than one contextual content. It may certainly elicit different reactions from different receptors. In one particular case the phrase may convey the request for an apple, in another instance it may be meant as an apology for having eaten somebody else's apple, and sometimes it may be used just to express the speaker's appreciation of the delicious fruit. The phrase may be the true reflection of the speaker's preference or it may be prompted by some hidden intention on his part. The same goes for the response of the receptor who may offer an apple to the speaker, ignore the request, resent the speaker's insolence, etc. We can say that each time we have to do with a different message, with a different text content.

Does that mean that the sentence "I like apples" will have a different translation into a foreign language each time its contextual content is changed ? The answer is obvious. As a rule, the translation will be the same. In each case it is only the semantic content of the phrase that will be rendered in translation and its receptors will project it against the particular contextual situation just as they do it with the semantic content of an original text.

This is not to say that in the process of translation the phrase may not be modified, formally or semantically. Let us suppose that it is to be translated into a hypothetic language where the speakers refer to themselves in the third person, where fruit cannot be "liked" but only "accepted", or where apples are unknown and cannot be referred to unless in a descriptive way. As a result, the translated phrase would be something like "He accepts such exotic fruit". Obviously, the modifications would be necessitated by the differences in the semantic structures of the two languages but not by the demands of the specific contexts in which the phrase was used or the cognitive knowledge of a particular receptor. If the ignorance of what an apple is can be regarded as a specific characteristic of the receptor, he shares it with other people speaking the same language and possesses it as a member of a linguistic community but not as an individual with his own cognitive knowledge.

The restrictive view of the text as the product of an individual act of communication produced under irreproducible unique conditions is in danger of overlooking some essential features of the text as a vehicle of communication which can externalize and fix human thoughts. Every act of communication is unique so far as it occurs between the particular communicants in a certain place at a certain time and with a particular intention. In this respect no act of communication can be repeated, no more than the same river can be entered twice. Then how can the translator hope to reproduce it in another language? His chance is the fact that communication is effected through the text, that is, a set of properly organized language units. And the interworking of the meanings of these units results in the formation of text semantics of relative stability. The text and its 
semantic content continue to exist after the completion of the individual act of communication for which it has been produced. It is perpetuated in its written or oral (recorded) form and is alienated thereby from the original communication, preserving its communicative potential. It can now transmit its inherent information again and again to all receptors who know the language. This is the most important function of the recorded speech units, which fix and preserve the cognitive knowledge in their semantics, making it available to any number of communicants of today and tomorrow.

Summing up, we can say that, on the one hand, the text conveys some specific here-and-now message that is produced under the given circumstances for the given receptor with his individual cognitive knowledge and is therefore subjective, existing, as it were, for this particular receptor alone. But, on the other hand, the text contains information accessible to any receptor who knows the language, and which is in this respect objective, dependent on the language units' meanings and independent of the possible differences in the cognitive knowledge of each receptor. In subsequent acts of communication the information contained in the text can be extracted from it owing to the interaction of its semantics with the cognitive knowledge of each new receptor and the additional information he gets from the contextual situation. Thus the semantic is the permanent factor in this interaction while the other factors may change as soon as a different receptor is involved or the communication is effected under different circumstances.

It follows that the semantic plays no minor role in solving the problem of translation equivalence. In a sense the translation may be more or less equivalent to the source text irrespective of when, where or which member of the target language community will try to get its message. As a rule, the translator tries to produce in the target language "the closest natural equivalent" to the source text semantics' modifying it, whenever necessary, to comply with the semantic rules of the target language and to account for the cultural or historical specifics of the language community. Each receptor of the translation text extracts its message in the same way as he handles original texts in his own language, projecting its semantics against his cognitive knowledge and the conditions of communication. In case he fails to understand some of the information received because he lacks the necessary background knowledge, he looks for some reference materials just as he does when he encounters a similar difficulty in an original text. A lack of the cognitive knowledge required for in-depth understanding of the text content is a common occurrence in any language and it is not an exclusively translation problem. The theory of translation is primarily concerned with cases where this lack of knowledge results from the difference in the cultural or historical experience which is reflected, directly or indirectly, in the semantic structures of the respective languages.

The predominant orientation of the translation process towards the particular receptor and the specific circumstances of the particular act of communication, is sometimes justified in interpretation where the interpreter has a direct contact with the communicants and can take into account their individual knowledge, goals and moods. It is natural that interpreters tend to overlook the importance of the semantic and claim that they have to do not with language but with ideas.

In conclusion, I would like to reaffirm my conviction that the problem of translation equivalence involves all aspects of interlingual communication, both cognitive and semantic, constant and variable. But a viable equivalence concept must give prominence to the correlation between the semantic content of the source and the target texts. A disregard of the semantic is counterproductive in any theory of translation. 